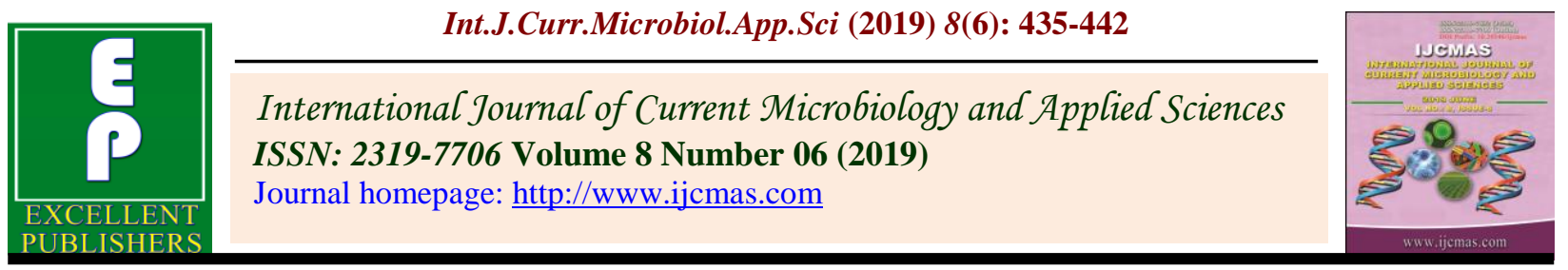

Original Research Article

https://doi.org/10.20546/ijcmas.2019.806.049

\title{
Knowledge of the Beneficiaries and Non-beneficiaries about Kisan Credit Card Scheme in Deoghar Block of Deoghar District, Jharkhand, India
}

\author{
Roshni Ritu Murmu*, Dipak Kumar Bose and Jahanara
}

Department of Agricultural Extension and Communication, Naini Agricultural Institute, Sam Higginbottom University of Agriculture Technology \& Sciences, Prayagraj, U.P, India

*Corresponding author

\begin{tabular}{|c|c|}
\hline & A B S T R A C T \\
\hline $\begin{array}{l}\text { Kisan Credit Card } \\
\text { Scheme, } \\
\text { Beneficiaries, Non- } \\
\text { beneficiaries, } \\
\text { Knowledge }\end{array}$ & \multirow{3}{*}{$\begin{array}{l}\text { The present investigation was undertaken in Deoghar block of Deoghar district in } \\
\text { Jharkhand. Purposive sampling was followed for the selection of one hundred and twenty } \\
\text { respondents, dividing them into two groups beneficiaries who were availing the benefits of } \\
\text { the Kisan Credit Card Scheme and non-beneficiaries who were not availing any benefits of } \\
\text { KCC Scheme. Pre-structured interview schedule was used to collect the data, collected } \\
\text { data were tabulated and analysed with suitable statistics to draw conclusion. The study } \\
\text { inferred that } 65 \text { per cent of beneficiaries had medium level of knowledge about the Kisan } \\
\text { Credit Card Scheme followed by } 20 \text { per cent who had high level and } 15 \text { per cent had low } \\
\text { level of knowledge. It was also noted that } 45 \text { per cent of non-beneficiaries had low } \\
\text { knowledge about the Kisan Credit Card Scheme followed by } 43.33 \text { per cent who had } \\
\text { medium and } 11.66 \text { per cent had high level of knowledge. }\end{array}$} \\
\hline Article Info & \\
\hline $\begin{array}{l}\text { Accepted: } \\
\text { 04 May } 2019 \\
\text { Available Online: } \\
\text { 10 June } 2019\end{array}$ & \\
\hline
\end{tabular}

\section{Introduction}

Agriculture has been the basis of Indian economy. Agriculture has been outpaced by the increasing technical and service sector development in the country although it is still a major contributor to the gross domestic product of the country. Over the period of time, the need of agriculture credit has also increased which has given rise to formal and informal sectors of lending.

Agriculture credit plays an important role in maintaining agricultural production by allowing producers to meet their credit requirement during the entire cycle of crop production and at the same time providing funds for investment purposes. With increased commercialization of agriculture and increase in the use of modern inputs, the amount and share of purchased inputs in the total production is increasing rapidly. Besides, private investment in different types of assets like irrigation equipments, farm machinery and land, improvements are required for efficient production and for maintaining faster agricultural output growth. Farmers have to avail credit either from institutional sources or from non- institutional sources like private money lenders which are though very 
common, but are often exploitative, with very high interest rate, and from such sources the borrowers often fall into debt trap. Realizing these difficulties, the government has initiated several measures to vitalize the institutional credit system to make it more responsive to the needs of farmers.

Kisan Credit Card (KCC) scheme was introduced by the National Bank for Agriculture and Rural Development (NABARD) in August 1998, on the recommendations of R. V. Gupta committee to provide term loans and agricultural needs to farmers on the basis of their land holdings for uniform adoption by the banks so that farmers may use timely and hassle free credit for their production requirements. The main purpose of the scheme was to meet the production as well as consumption needs of the farmers. It facilitates in providing financial assistance to the farmers to meet their credit needs in relation to production, consumption as well as other allied activities throughout the year as and when required.

\section{Materials and Methods}

The present study was conducted in Deoghar district of Jharkhand in the year 20182019.This district consists of 10 blocks out of which Deoghar block was selected purposively based on the availability of highest number of Kisan Credit Card Scheme beneficiaries. From the selected block twelve villages were selected purposively having large population availing the benefits of the scheme. Ten respondents were selected randomly from each village. Thus, altogether 120 respondents were selected and divided into two categories of beneficiaries $(n=60)$ and non-beneficiaries $(n=60)$. A wellstructured and pre-tested interview schedule was used to study the objectives and the data were collected using personal interview. The independent variables were namely age, education, type of family, size of family, occupation, annual income, size of land holding, mass media exposure, extension participation, innovativeness, progressiveness and dependent variables were knowledge and attitude. The collected data were tabulated and analysed in the light of the SPSS and the conclusion was drawn.

\section{Results and Discussion}

Change in knowledge precedes acceptance and application of an innovation, it is therefore always important to find out the factor responsible for positive or negative disposition associated with farmer towards the usefulness and application of a programme.

Table 1 clearly shows that among the beneficiaries 45 per cent population was of young age and among the non-beneficiaries nearly half i.e. 48.33 per cent population was of middle age. Talking about their education level the highest per cent of beneficiaries i.e. 25 per cent were the ones who attended high school and a large population of nonbeneficiaries 66.66 per cent were illiterate. The family type was primarily nuclear for the beneficiaries and consisted of 63.33 per cent whereas the family type of non beneficiaries was also mostly nuclear with 51.66 per cent. The maximum per cent i.e. 58.33 per cent of beneficiaries had farming as their occupation and 53.33 per cent non-beneficiaries also practiced farming. Both the categories of beneficiaries and non-beneficiaries had medium range of annual income comprising of 53.33 per cent and 45 per cent respectively. Maximum number of beneficiaries and nonbeneficiaries i.e. 61.66 per cent and 70 per cent respectively were marginal farmers. 48.33 per cent beneficiaries and 43.33 per cent non-beneficiaries used the mass media on a medium level. 40 per cent of the beneficiaries had medium extension 
participation and 41.66 per cent nonbeneficiaries had low extension participation. 50.00 per cent beneficiaries had medium innovativeness and 41.66 per cent nonbeneficiaries had low innovativeness. Coming to the progressiveness 45 per cent beneficiaries fell in medium category and 40 per cent in low category. Similar findings are also reported by Parwate et al., (2018).

Table 2 shows that 43.33 per cent beneficiaries had medium level of socioeconomic status followed by high comprising 30 per cent and low 26.66 per cent. The nonbeneficiaries had 42.50 per cent respondents who had medium socio-economic status followed by 36.66 per cent who had low and 21.66 who had high socio-economic status. The findings are in the line of the findings of Sharma (2013).

Table 3 shows that among the beneficiaries 43.33 per cent had high knowledge about the general details about Kisan Credit Card Scheme.68 per cent of the beneficiaries had partial knowledge about conversion and rescheduling of loan in case of damage to crops due to natural calamities followed by 65 per cent who knew about Mobile based transfer transactions. Also, 61.66 percent beneficiaries had partial knowledge regarding the scheme providing working capital for maintenance of farm assets and activities allied to agriculture as well as no restriction in number of debits and credits and repayment period of 12 months.

The 20 per cent beneficiaries had lowest knowledge that banks are to waive margin/security requirements for up to a credit limit of $1.00 \mathrm{Lakh}$. It was noted that the highest percentage of non-beneficiaries i.e. 48 per cent had partial knowledge about the eligibility criteria to avail KCC Scheme and issuing of Smart card/Debit card to the beneficiaries under the scheme. It was surprising to know that nearly half i.e. 40 per cent of the non beneficiaries had no knowledge regarding mobile based transfer transactions under this scheme as well as the fact that banks are to waive margin/security requirements for upto a credit limit of 1.00 Lakh.38.33 per cent non-beneficiaries also had no knowledge that the scheme provides the loan for the Rabi and Kharif crop production not for Jaid crop Production, that there is no restriction in number of debits and credits in KCC Scheme and that conversion/rescheduling of loans are also permissible in case of damage to crops due to natural calamities.

It is clear from Table 4 that with respect to overall level of knowledge; mean frequencies suggested that 65 percent of beneficiaries had medium knowledge about the Kisan Credit Card Scheme, while 20 percent of the beneficiaries had high level of knowledge regarding the Scheme followed by 15 per cent beneficiaries who had low level of knowledge. The table also shows that 45 per cent of non-beneficiaries had Low knowledge about the Kisan Credit Card Scheme, while 43.33 per cent of the non-beneficiaries had medium level of knowledge regarding the Scheme followed by 11.66 per cent beneficiaries who had high level of knowledge. Similar findings are also reported by Santhi (2012).

$\mathrm{X}^{2} \quad 2 \quad(5 \%)$ (Tabulated valued) $=5.99, \mathrm{X}^{2}$ $($ Calculated value $)=7.6, \mathrm{~d} . \mathrm{f}=2$ degree of freedom at $5 \%$ level.

Since the calculated value of Chi square test is greater than the tabulated value of 2 degree of freedom at $5 \%$ probability level, so the null hypothesis is rejected. Therefore it can be concluded that there is significant relationship between socio-economic profile and knowledge level of the respondents. 
Int.J.Curr.Microbiol.App.Sci (2019) 8(6): 435-442

Table.1 Distribution of the respondents according to their Socio-economic profile

\begin{tabular}{|c|c|c|c|}
\hline Variables & Categories & $\begin{array}{c}\text { Beneficiaries } \\
\mathbf{F}(\%)\end{array}$ & $\begin{array}{c}\text { Non } \\
\text {-beneficiaries } \\
\text { F(\%) }\end{array}$ \\
\hline \multirow[t]{3}{*}{ Age } & a)30-40 yrs (Young) & $\begin{array}{c}27 \\
(45.00 \%)\end{array}$ & $\begin{array}{c}17 \\
(28.33 \%)\end{array}$ \\
\hline & b)41-50 yrs (Middle) & $\begin{array}{c}22 \\
(36.66 \%)\end{array}$ & $\begin{array}{c}29 \\
(48.33 \%)\end{array}$ \\
\hline & c) 51 yrs and above (Old) & $\begin{array}{c}11 \\
(18.33 \%)\end{array}$ & $\begin{array}{c}14 \\
(23.33 \%)\end{array}$ \\
\hline \multirow[t]{7}{*}{ Education } & a) Illiterate & $\begin{array}{c}5 \\
(08.33 \%)\end{array}$ & $\begin{array}{c}10 \\
(66.66 \%)\end{array}$ \\
\hline & b)Literate & $\begin{array}{c}10 \\
(16.66 \%)\end{array}$ & $\begin{array}{c}14 \\
(23.33 \%)\end{array}$ \\
\hline & c)Primary & $\begin{array}{c}11 \\
(18.33 \%)\end{array}$ & $\begin{array}{c}17 \\
(28.33 \%)\end{array}$ \\
\hline & d)Middle & $\begin{array}{c}5 \\
(08.33 \%)\end{array}$ & $\begin{array}{c}9 \\
(15.00 \%)\end{array}$ \\
\hline & e)High School & $\begin{array}{c}15 \\
(25.00 \%)\end{array}$ & $\begin{array}{c}5 \\
(8.33 \%)\end{array}$ \\
\hline & f)Intermediate & $\begin{array}{c}10 \\
(16.66 \%)\end{array}$ & $\begin{array}{c}4 \\
(6.66 \%)\end{array}$ \\
\hline & g)Graduate and above & $\begin{array}{c}4 \\
(6.66 \%)\end{array}$ & $\begin{array}{c}1 \\
(1.66 \%)\end{array}$ \\
\hline \multirow[t]{2}{*}{ Family type } & Nuclear family & $\begin{array}{c}38 \\
(63.33 \%)\end{array}$ & $\begin{array}{c}31 \\
(51.66 \%)\end{array}$ \\
\hline & Joint family & $\begin{array}{c}22 \\
(36.66 \%)\end{array}$ & $\begin{array}{c}29 \\
(48.33 \%)\end{array}$ \\
\hline \multirow[t]{3}{*}{$\begin{array}{l}\text { Occupa } \\
\text {-tion }\end{array}$} & Farming & $\begin{array}{c}35 \\
(58.33 \%)\end{array}$ & $\begin{array}{c}32 \\
(53.33 \%)\end{array}$ \\
\hline & Farming + business & $\begin{array}{c}18 \\
(30.00 \%)\end{array}$ & $\begin{array}{c}25 \\
(41.66 \%)\end{array}$ \\
\hline & Farming + services & $\begin{array}{c}7 \\
(11.66 \%)\end{array}$ & $\begin{array}{c}3 \\
(5.00 \%)\end{array}$ \\
\hline \multirow[t]{3}{*}{$\begin{array}{c}\text { Annual } \\
\text { income }\end{array}$} & Low (30000-50000) & $\begin{array}{c}16 \\
(26.66 \%)\end{array}$ & $\begin{array}{c}25 \\
(41.66 \%)\end{array}$ \\
\hline & Middle $(50001-70000)$ & $\begin{array}{c}32 \\
(53.33 \%)\end{array}$ & $\begin{array}{c}27 \\
(45.00 \%)\end{array}$ \\
\hline & High $(70001-90000)$ & $\begin{array}{c}12 \\
(20.00 \%)\end{array}$ & $\begin{array}{c}8 \\
(13.33 \%)\end{array}$ \\
\hline \multirow[t]{2}{*}{$\begin{array}{l}\text { Size of land } \\
\text { holding }\end{array}$} & Marginal (up to 1 ha) & $\begin{array}{c}37 \\
(61.66 \%)\end{array}$ & $\begin{array}{c}42 \\
(70.00 \%)\end{array}$ \\
\hline & Small (2-4ha) & $\begin{array}{c}18 \\
(30.00 \%)\end{array}$ & $\begin{array}{c}14 \\
(23.33 \%)\end{array}$ \\
\hline
\end{tabular}




\begin{tabular}{|c|c|c|c|}
\hline & Large (above 4ha) & $\begin{array}{c}5 \\
(8.33 \%)\end{array}$ & $\begin{array}{c}4 \\
(6.66 \%)\end{array}$ \\
\hline \multirow[t]{3}{*}{$\begin{array}{l}\text { Mass media } \\
\text { exposure }\end{array}$} & High & $\begin{array}{c}23 \\
(38.33 \%)\end{array}$ & $\begin{array}{c}14 \\
(23.33 \%)\end{array}$ \\
\hline & Medium & $\begin{array}{c}29 \\
(48.33 \%)\end{array}$ & $\begin{array}{c}26 \\
(43.33 \%)\end{array}$ \\
\hline & Low & $\begin{array}{c}8 \\
(13.33 \%)\end{array}$ & $\begin{array}{c}20 \\
(33.33 \%)\end{array}$ \\
\hline \multirow[t]{3}{*}{$\begin{array}{l}\text { Innovative } \\
\text {-ness }\end{array}$} & Low (7-11 score) & $\begin{array}{c}13 \\
(21.66 \%)\end{array}$ & $\begin{array}{c}25 \\
(41.66 \%)\end{array}$ \\
\hline & Medium(11-14 score) & $\begin{array}{c}30 \\
(50.00 \%)\end{array}$ & $\begin{array}{c}24 \\
(40.00 \%)\end{array}$ \\
\hline & High (14-18 score) & $\begin{array}{c}17 \\
(28.33 \%)\end{array}$ & $\begin{array}{c}11 \\
(18.33 \%)\end{array}$ \\
\hline \multirow[t]{3}{*}{$\begin{array}{l}\text { Progressive } \\
\text {-ness }\end{array}$} & Low (below 9 score) & $\begin{array}{c}21 \\
(35.00 \%)\end{array}$ & $\begin{array}{c}18 \\
(30.00 \%)\end{array}$ \\
\hline & Medium ( $10-13$ score) & $\begin{array}{c}26 \\
(43.33 \%)\end{array}$ & $\begin{array}{c}27 \\
(45.00 \%)\end{array}$ \\
\hline & High (14 - above score) & $\begin{array}{c}13 \\
(21.66 \%)\end{array}$ & $\begin{array}{c}15 \\
(25.00 \%)\end{array}$ \\
\hline
\end{tabular}

Table.2 Overall socio-economic level of the respondents

\begin{tabular}{|c|c|c|c|}
\hline $\begin{array}{c}\text { Socio-economic } \\
\text { Level }\end{array}$ & $\begin{array}{l}\text { Beneficiaries } \\
\quad(n=60)\end{array}$ & $\begin{array}{c}\text { Non- } \\
\text { beneficiaries } \\
(\mathbf{n}=60)\end{array}$ & $\begin{array}{c}\text { Total } \\
(\mathbf{n}=120)\end{array}$ \\
\hline Low & $\begin{array}{l}16 \\
(26.66 \%)\end{array}$ & $\begin{array}{c}22 \\
(36.66 \%)\end{array}$ & $\begin{array}{c}38 \\
(31.66 \%)\end{array}$ \\
\hline Medium & $\begin{array}{l}26 \\
(43.33 \%)\end{array}$ & $\begin{array}{c}25 \\
(41.66 \%)\end{array}$ & $\begin{array}{c}51 \\
(42.50 \%)\end{array}$ \\
\hline High & $\begin{array}{l}18 \\
(30.00 \%)\end{array}$ & $\begin{array}{c}13 \\
(21.66 \%)\end{array}$ & $\begin{array}{c}31 \\
(25.83 \%)\end{array}$ \\
\hline Total & 60 & 60 & 120 \\
\hline
\end{tabular}


Table.3 Distribution of the respondents according to their knowledge about Kisan Credit Card Scheme

\begin{tabular}{|c|c|c|c|c|c|c|c|}
\hline & & & & & & \multicolumn{2}{|c|}{$\mathrm{N}=120(60+60)$} \\
\hline \multirow{2}{*}{$\begin{array}{l}\text { S. } \\
\text { No. }\end{array}$} & \multirow[b]{2}{*}{ Statements } & B & NB & B & NB & B & NB \\
\hline & & \multicolumn{2}{|c|}{$\begin{array}{c}\mathbf{F C} \\
\mathbf{F}(\%)\end{array}$} & \multicolumn{2}{|c|}{$\begin{array}{c}\mathbf{P C} \\
\mathbf{F}(\%)\end{array}$} & \multicolumn{2}{|c|}{$\begin{array}{l}\text { IC } \\
\text { F }(\%)\end{array}$} \\
\hline 1. & $\begin{array}{l}\text { Known the general detail } \\
\text { about Kisan Credit Card } \\
\text { Scheme }\end{array}$ & $\begin{array}{c}26 \\
(43.33 \%)\end{array}$ & $\begin{array}{c}14 \\
(23.33 \%)\end{array}$ & $\begin{array}{c}28 \\
(46.66 \%)\end{array}$ & $\begin{array}{c}25 \\
(41.66 \%)\end{array}$ & $\begin{array}{c}6 \\
(10 \%)\end{array}$ & $\begin{array}{c}21 \\
(35.00 \%)\end{array}$ \\
\hline 2. & $\begin{array}{l}\text { Eligibility criteria to avail } \\
\text { KCC Scheme is known }\end{array}$ & $\begin{array}{c}20 \\
(33.33 \%)\end{array}$ & $\begin{array}{c}11 \\
(18.33 \%)\end{array}$ & $\begin{array}{c}32 \\
(53.33 \%)\end{array}$ & $\begin{array}{c}29 \\
(48.33 \%)\end{array}$ & $\begin{array}{c}8 \\
(13.33 \%)\end{array}$ & $\begin{array}{c}20 \\
(33.33 \%)\end{array}$ \\
\hline 3. & $\begin{array}{l}\text { The Tenure limit of KCC } \\
\text { Scheme is known }\end{array}$ & $\begin{array}{c}17 \\
(28.33 \%)\end{array}$ & $\begin{array}{c}12 \\
(20.00 \%)\end{array}$ & $\begin{array}{c}36 \\
(60.00 \%)\end{array}$ & $\begin{array}{c}28 \\
(46.66 \%)\end{array}$ & $\begin{array}{c}7 \\
(13.33 \%)\end{array}$ & $\begin{array}{c}20 \\
(33.33 \%)\end{array}$ \\
\hline 4. & $\begin{array}{l}\text { KCC covers Crop well as } \\
\text { personal insurance }\end{array}$ & $\begin{array}{c}18 \\
(30.00 \%)\end{array}$ & $\begin{array}{c}14 \\
(23.33 \%)\end{array}$ & $\begin{array}{c}36 \\
(60.00 \%)\end{array}$ & $\begin{array}{c}26 \\
(43.33 \%)\end{array}$ & $\begin{array}{c}6 \\
(10.00 \%)\end{array}$ & $\begin{array}{c}20 \\
(33.33 \%)\end{array}$ \\
\hline 5. & $\begin{array}{l}\text { Knowledge that it provides } \\
\text { the loan for the Rabi and } \\
\text { Kharif crop production } \\
\text { not for Jaid crop } \\
\text { Production. }\end{array}$ & $\begin{array}{c}14 \\
(23.33 \%)\end{array}$ & $\begin{array}{c}11 \\
(18.33 \%)\end{array}$ & $\begin{array}{c}39 \\
(65.00 \%)\end{array}$ & $\begin{array}{c}26 \\
(43.33 \%)\end{array}$ & $\begin{array}{c}7 \\
(11.66 \%)\end{array}$ & $\begin{array}{c}23 \\
(38.33 \%)\end{array}$ \\
\hline 6. & $\begin{array}{l}\text { KCC provides working } \\
\text { capital } \\
\text { for maintenance of farm } \\
\text { assets and activities allied } \\
\text { to agriculture }\end{array}$ & $\begin{array}{c}13 \\
(21.66 \%)\end{array}$ & $\begin{array}{c}10 \\
(16.66 \%)\end{array}$ & $\begin{array}{c}37 \\
(61.66 \%)\end{array}$ & $\begin{array}{c}28 \\
(46.66 \%)\end{array}$ & $\begin{array}{c}10 \\
(16.66 \%)\end{array}$ & $\begin{array}{c}22 \\
(36.66 \%)\end{array}$ \\
\hline 7. & $\begin{array}{l}\text { The beneficiaries under } \\
\text { the } \\
\text { scheme are issued with a } \\
\text { Smart card / Debit card }\end{array}$ & $\begin{array}{c}17 \\
(28.33 \%)\end{array}$ & $\begin{array}{c}12 \\
(20.00 \%)\end{array}$ & $\begin{array}{c}36 \\
(60.00 \%)\end{array}$ & $\begin{array}{c}29 \\
(48.33 \%)\end{array}$ & $\begin{array}{c}7 \\
(11.66 \%)\end{array}$ & $\begin{array}{c}19 \\
(31.66 \%)\end{array}$ \\
\hline 8. & $\begin{array}{l}\text { KCC allows mobile based } \\
\text { transfer transactions at } \\
\text { agricultural input dealer } \\
\text { and mandies. }\end{array}$ & $\begin{array}{c}11 \\
(18.33 \%)\end{array}$ & $\begin{array}{c}11 \\
(18.33 \%)\end{array}$ & $\begin{array}{l}39 \\
(65.00 \%)\end{array}$ & $\begin{array}{c}25 \\
(41.66 \%)\end{array}$ & $\begin{array}{c}10 \\
(16.66 \%)\end{array}$ & $\begin{array}{c}24 \\
(40.00 \%)\end{array}$ \\
\hline 9. & $\begin{array}{l}\text { There is no restriction in } \\
\text { number of debits and } \\
\text { credits in KCC Scheme }\end{array}$ & $\begin{array}{l}15 \\
(25.00 \%)\end{array}$ & $\begin{array}{c}11 \\
(18.33 \%)\end{array}$ & $\begin{array}{c}37 \\
(61.66 \%)\end{array}$ & $\begin{array}{c}27 \\
(45.00 \%)\end{array}$ & $\begin{array}{c}8 \\
(13.33 \%)\end{array}$ & $\begin{array}{c}23 \\
(38.33 \%)\end{array}$ \\
\hline 10. & $\begin{array}{l}\text { For KCC limit upto } \square \\
1.00 \text { lakh banks are to } \\
\text { waive margin/security } \\
\text { requirements. }\end{array}$ & $\begin{array}{c}12 \\
(20.00 \%)\end{array}$ & $\begin{array}{c}9 \\
(15.00 \%)\end{array}$ & $\begin{array}{c}36 \\
(60.00 \%)\end{array}$ & $\begin{array}{c}27 \\
(45.00 \%)\end{array}$ & $\begin{array}{c}12 \\
(20.00 \%)\end{array}$ & $\begin{array}{c}24 \\
(40.00 \%)\end{array}$ \\
\hline 11. & $\begin{array}{l}\text { Amount withdrawn have } \\
\text { to be paid within } 12 \\
\text { months }\end{array}$ & $\begin{array}{c}16 \\
(26.66 \%)\end{array}$ & $\begin{array}{c}13 \\
(21.66 \%)\end{array}$ & $\begin{array}{c}37 \\
(61.66 \%)\end{array}$ & $\begin{array}{c}26 \\
(43.33 \%)\end{array}$ & $\begin{array}{c}7 \\
(11.66 \%)\end{array}$ & $\begin{array}{c}21 \\
(35.00 \%)\end{array}$ \\
\hline 12. & $\begin{array}{l}\text { Conversion/rescheduling } \\
\text { of loans also permissible } \\
\text { in case of damage to crops } \\
\text { due to natural calamities. }\end{array}$ & $\begin{array}{c}10 \\
(16.66 \%)\end{array}$ & $\begin{array}{c}11 \\
(18.33 \%)\end{array}$ & $\begin{array}{c}41 \\
(68.33 \%)\end{array}$ & $\begin{array}{c}26 \\
(43.33 \%)\end{array}$ & $\begin{array}{c}9 \\
(15.00 \%)\end{array}$ & $\begin{array}{c}23 \\
(38.33 \%)\end{array}$ \\
\hline
\end{tabular}

*FC-Fully Correct, PC-Partially Corred,IC-Incorrect,F-Frequency,B-Beneficiaries,NB-Non-beneficiaries 
Table.4 Knowledge level of the respondents about kisan credit card scheme

\begin{tabular}{|l|c|c|c|}
\hline \multicolumn{1}{|c|}{ Categories } & $\begin{array}{c}\text { Beneficiaries } \\
(\mathbf{n = 6 0})\end{array}$ & $\begin{array}{c}\text { Non-beneficiaries } \\
(\mathbf{n = 6 0})\end{array}$ & $\begin{array}{c}\text { Total } \\
(\mathbf{n = 1 2 0})\end{array}$ \\
\hline Low(12-20) & $09(15.00 \%)$ & $27(45.00 \%)$ & $36(30.00 \%)$ \\
\hline Medium(21-29) & $39(65.00 \%)$ & $26(43.33 \%)$ & $65(54.16 \%)$ \\
\hline High(30-38) & $12(20.00 \%)$ & $7(11.66 \%)$ & $19(15.83 \%)$ \\
\hline Total & $\mathbf{6 0}$ & $\mathbf{6 0}$ & $\mathbf{1 2 0}$ \\
\hline
\end{tabular}

Table.5 Association between the Socio-economic profile and Knowledge level of the beneficiaries

\begin{tabular}{|c|c|c|c|c|}
\hline & & \multicolumn{3}{|c|}{$n=60$} \\
\hline S.NO & Category & Knowledge & S.E.S & Row \\
\hline 1. & Low & $\begin{array}{c}09(\mathrm{a}) \\
(13.5)=\mathrm{Ea}\end{array}$ & $\begin{array}{c}16(b) \\
(13.5)=E b\end{array}$ & $\mathrm{R} 1_{(\mathrm{a}+\mathrm{b})}$ \\
\hline 2. & Medium & $\begin{array}{c}39(\mathrm{c}) \\
(31.5)=\mathrm{Ec}\end{array}$ & $\begin{array}{c}26(d) \\
(31.5)=E d\end{array}$ & $\begin{array}{c}63 \\
R 2{ }_{(c+d)}\end{array}$ \\
\hline 3. & High & $\begin{array}{c}12(\mathrm{e}) \\
(15)=\mathrm{E} \mathrm{e}\end{array}$ & $\begin{array}{c}18(f) \\
(15)=E f\end{array}$ & $\begin{array}{c}30 \\
R 3_{(e+f)}\end{array}$ \\
\hline 4. & Column total & 60 & 60 & $120=N$ \\
\hline
\end{tabular}

Ea $=$ Expected value of $\mathrm{a} ;(\mathrm{a})=$ Observed value

Table.6 Association between the Socio-economic profile and Knowledge level of the nonbeneficiaries

\begin{tabular}{|c|c|c|c|c|}
\hline \multicolumn{5}{|r|}{$n=60$} \\
\hline S.NO & Category & Knowledge & S.E.S & Row \\
\hline 1. & Low & $\begin{array}{c}27(a) \\
(24.5)=\mathrm{Ea}\end{array}$ & $\begin{array}{c}22(b) \\
(24.5)=E b\end{array}$ & $\begin{array}{c}49 \\
\mathrm{R} 1_{(\mathrm{a}+\mathrm{b})}\end{array}$ \\
\hline 2. & Medium & $\begin{array}{c}26(c) \\
(25.5)=\mathrm{Ec}\end{array}$ & $\begin{array}{c}25(\mathrm{~d}) \\
(25.5)=\mathrm{Ed}\end{array}$ & $\begin{array}{c}51 \\
\mathrm{R} 2{ }_{(\mathrm{c}+\mathrm{d})}\end{array}$ \\
\hline 3. & High & $\begin{array}{c}7(\mathrm{e}) \\
(10)=\mathrm{Ee}\end{array}$ & $\begin{array}{c}13(f) \\
(10)=\mathrm{Ef}\end{array}$ & $\begin{array}{c}20 \\
R 3_{(e+f)}\end{array}$ \\
\hline 4. & $\begin{array}{l}\text { Column } \\
\text { total }\end{array}$ & 60 & 60 & $120=N$ \\
\hline
\end{tabular}

Ea $=$ Expected value of $\mathrm{a} ;(\mathrm{a})=$ Observed value 
$X^{2} \quad 2 \quad(5 \%)$ (Tabulated valued) $=5.99, \quad X^{2}$ (Calculated value $)=2.318$, d.f $=2$ degree of freedom at $5 \%$ level.

Since the calculated value of Chi square test is lesser than the tabulated value of 2 degree of freedom at 5\% probability level, so the null hypothesis is accepted. Therefore it can be concluded that there is non-significance.

It is concluded that majority of the K.C.C beneficiaries have medium to high level of socio-economic status followed by medium to low level in case of K.C.C non-beneficiaries. It was found that beneficiaries and nonbeneficiaries both have medium level of knowledge but there is statistically significant difference between the knowledge level of both categories (Table 5 and 6). It was also found that proper training and extension strategies are to be followed for improvement of knowledge level of the beneficiaries as well as to increase farmer's participation in availing the benefits of the scheme. This will also be helpful in using the K.C.C properly leading to the development of agriculture sector.

\section{References}

Bista Diwas Raj et al., (2012) Progress and Performance of Kisan Credit Card Scheme with a Case Study of Bihar. Agricultural Economics Research Review Vol. 25, No.1.

Chandra V. (2005) Profile of Sujala watershed project beneficiary farmers in Dharwad district. M.Sc. (Agri.) Thesis submitted to University of Agricultural Sciences, Dharwad.

Dhanabhakyam M. et al., (2012) A study on the awareness, utilization and problems of using Kisan Credit Card of Canara bank [with special reference to Coimbatore district]. IRJC International Journal of Marketing, Financial Services \& Management Research Vol.1 Issue 10, October 2012.

Hirwe Rajendra et al., (2016) Impact of Kisan credit card scheme among the beneficiary farmers in Maheshwar block, Khargone district of M.P. International Journal of Humanities and Social Science Research, ISSN: 2455-2070; Volume 2; Issue 8; pp. 2022.

Lahiri Biswajit (2016) Agricultural information seeking behaviour of Garo tribal framers of Meghalaya, India. Eco. Env. \& Cons. 22.

Parwate P.P et al., (2018) Satisfaction of farmers about Kisan Credit Card in Raipur district of Chattisgarh. International Journal of Agriculture Science, Vol. 10, issue 21, Pp. 7441-7444.

Prakash and Arul (2004) Analysis of Swarnajayanti Gram Swarozgar Yojana in Salem and Thiruvallur district of Tamil Nadu, M.Sc. (Agri.) Thesis submitted to University of Agricultural Sciences, Dharwad.

Sharma Arvind et al. (2013) A Study on Impact of Kisan Credit Card Scheme among the Beneficiary Farmers in Sehore District of Madhya Pradesh. International Journal of Science and Research (IJSR), India Online Volume 2 Issue 1.

\section{How to cite this article:}

Roshni Ritu Murmu, Dipak Kumar Bose and Jahanara. 2019. S Knowledge of the Beneficiaries and Non-beneficiaries about Kisan Credit Card Scheme in Deoghar Block of Deoghar District, Jharkhand. Int.J.Curr.Microbiol.App.Sci. 8(06): 435-442.

doi: https://doi.org/10.20546/ijcmas.2019.806.049 